\title{
Retrospective Evaluation of the Performance of Leukocyte Parameter of the Automated Urine Analyzer and Its Concordance with Urine Culture
}

\author{
Otomatik idrar analizörü lökosit parametresi performansının \\ retrospektif değerlendirmesi ve idrar kültürü ile uyumu
}



\author{
${ }^{1}$ Department of Biochemistry, Silivri State Hospital, Istanbul, Turkey \\ ${ }^{2}$ Department of Biochemistry, University of Health Sciences, Dr. Sadi Konuk Training and Research Hospital, Istanbul, Turkey

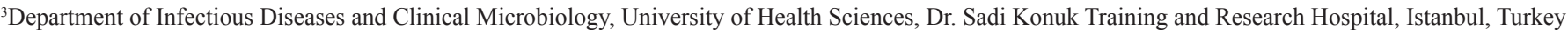 \\ ${ }^{4}$ Department of Medical Oncology, University of Health Sciences, Dr. Sadi Konuk Training and Research Hospital, Istanbul, Turkey \\ ${ }^{5}$ Department of Urology, University of Health Sciences, Regional Training and Research Hospital, Erzurum, Turkey \\ ${ }^{6}$ Department of Urology, Dr. Sadi Konuk Training and Research Hospital, Health Sciences University, Istanbul, Turkey
}

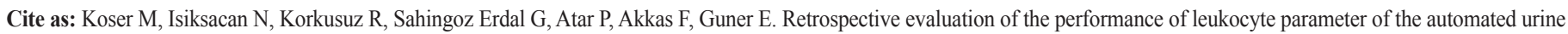
analyzer and its concordance with urine culture. Grand J Urol 2021;1(2):55-61.

Submission date: 16 March $2021 \quad$ Acceptance date: 21 April $2021 \quad$ Online first: 26 April $2021 \quad$ Publication date: 20 May 2021


nisiksacan@gmail.com ORCID ID: 0000-0002-0230-6500

\begin{abstract}
Objective: Complete urinalysis (CUA) is one of the indispensable screening tests of clinical laboratories. The compatibility of this test with urine culture is of indispensable importance in the diagnosis and treatment of urinary tract infections. We aimed to evaluate the suitability of the leukocyte parameter measured in the microscopic units of the fully automated urine analyzers which replace traditional methods, by grouping them according to the results of chemical analysis.

Materials and Methods: Leukocyte counts in the reported CUA results of 4685 outpatients and the results of 113 urine cultures studied on the same day were analyzed. Noncentrifugated urine samples were included in the analysis. Cells were digitally imaged by flow microscopy. Chemical analyzes were performed using dual wavelength reflectance method. Urine samples were evaluated after 24 hours of incubation.

Results: High power field (HPF) values were recorded by grouping the leukocyte counts as negative, trace, $1+, 2+$ and $3+$. The arithmetic means of HPF values of the groups were calculated as 1.2, 2.1, 5.0, 11 and 208 white blood cell (WBCs/HPF). Bacterial growth was detected in 19 of 113 patients and no reproduction was observed in the remaining 94 cases. When results of microscopic examinations and chemical analysis were compared with the culture results, the analytical sensitivity, specificity, positive, and negative predictive values for microscopic urinalysis were $25 \%, 86 \%, 61.3 \%$, and $58.3 \%$, respectively. While, the analytical sensitivity, specificity, positive, and negative predictive values for chemical analysis of urine were $25.8 \%, 87.7 \%, 69.7 \%$, and $51.4 \%$, respectively

Conclusion: The workload of medical laboratories is increasing, and the use of urine autoanalyzers may be preferred for busy laboratories. In the diagnosis and follow-up of urinary tract infections, complete urinalysis by autoanalysers in which the harmony of their microscopy and chemical units are closely monitored, may reduce the need for unnecessary requests for urine culture, but it cannot replace urine culture.
\end{abstract}

Keywords: complete urinalysis, automated urine analyzer, urine culture, HPF, leukocyte

Öz

Amaç: Tam idrar tahlili (TITT), klinik laboratuvarların vazgeçilemez tarama testlerinden biridir. Bu testin idrar kültürü ile olan uyumu, idrar yolu infeksiyonlarının tanı ve tedavisinde vazgeçilemeyecek bir önem taşır. Geleneksel metodların yerini alan tam otomatik idrar analizi yapan cihazların mikroskobik ünitelerinde ölçülen lökosit parametresinin kimyasal analiz sonuçlarına göre gruplandırılması yapılarak aynı gün yapılan idrar kültürleri ile olan uygunluğunun değerlendirilmesi amaçlanmışıır.

Gereçler ve Yöntemler: Ayaktan başvuran 4685 hastanın raporlanmıș TíT sonuçlarındaki lökosit değerleri ve aynı gün çalışılmıs 113 idrar kültürü sonuçları incelenmiștir. İdrar örnekleri santrifüj edilmeden dahil edilmiştir. Hücreler flow mikroskobi ile dijital olarak görüntülenmiştir. Kimyasal analizler dual dalga boyu reflektans metodu kullanılarak yapılmıștır. İdrar örnekleri ise 24 saat inkübasyon sonrası değerlendirilmiștir.

Bulgular: Lökosit ölçümleri negatif, eser, 1+, 2+ ve 3+ olarak gruplandırılarak yüksek güç alanı (HPF) değerleri kaydedilmiştir. Gruplara ait aritmetik ortalama HPF değerleri ise 1.2, 2.1, 5.0,11 ve 208 HPF olarak hesaplanmıștır. 113 hastanın 19'unda üreme saptanmıs, 94'ünde ise üreme olmamıștır. Mikroskopi ve kimyasal analiz sonuçları kültür sonuçları ile karşılaştırıldığında, idrar mikroskopisi için duyarlık \%25, özgüllük \%86, pozitif prediktif değer \%61,3, negatif prediktif değer $\% 58,3$ bulunmuștur. İdrarın kimyasal analizi için duyarlık \%25,8, özgüllük \%87,7, pozitif prediktif değer \%69,7, negatif prediktif değer \%51,4 olarak saptanmıștır. Sonuç: Tıbbi laboratuvarların iş yükü giderek artmakta olup yoğun laboratuvarlar için idrar otoanalizörünün kullanımı tercih nedeni olabilir. İdrar yolu enfeksiyonu tanı ve takibinde, mikroskobi ve kimyasal ünitelerinin uyumunun sıkı takip edildiği otoanalizörlerle TíT yapılması, gereksiz idrar kültürü istenmesini ve idrar kültürüne olan ihtiyacı azaltabilse de idrar kültürünün yerini almamaktadır.

Anahtar kelimeler: tam idrar tahlili, otomatik idrar analizörü, idrar kültürü, HPF, lökosit

ORCID ID: M. Koser 0000-0001-7102-0875

R. Korkusuz 0000-0002-9988-9596
G. Sahingoz Erdal $\quad 0000-0001-5815-5847$

P. Atar
0000-0003-1703-2204
F. Akkas

0000-0002-4560-7426

0000-0002-4770-7535 


\section{Introduction}

Urinary tract infection (UTI) is one of the most common infections. Most women experience UTI at least once in their lifetime [1]. The most common microorganisms are gram- negative enteric bacteria. Most prevalently Escherichia coli is grown in urine cultures. Bacterial growth due to contamination in urine culture is seen at a rate of $29-32 \%$ which is one of the problems that complicate clinical evaluation $[2,3]$.

Complete urinalysis (CUA) is one of the fast, reliable, easy, cheap and sensitive screening tests of clinical laboratories. The compatibility of this test with urine culture is very important in both children and adults. CUA is used often especially in the diagnosis of urinary tract infections, selection of treatment and monitoring recovery. CUA also helps in the differential diagnosis of diseases and it is necessary to be able to initiate treatment as early as possible [4].

Today, as a result of the increasing workload and technological developments, traditional methods are replaced by fully automated urine analyzers. In this study, we aimed to group the leukocyte parameter measured in microscopic units of fully automated urine analyzers according to the results of chemical analysis and to evaluate its compatibility with urine cultures performed on the same day.

\section{Materials and Methods}

Local ethics committee approval was obtained prior to study (approval number: 2019/506). Outpatients who were admitted to our hospital whose urinalyses were requested from different polyclinics with different pre-diagnoses between November 2010 and February 2011 were included in the study.

Results of 113 urine cultures, and 4685 leukocyte counts performed using an automated urine analyzer on the same day were retrospectively analyzed and evaluated. Noncentrifuged urine samples were included in the analyses. Cells were digitally imaged by flow microscopy method. Chemical analyzes were made using the dual wavelength reflectance method. (IRIS IQ200, Beckman Coulter, USA).

High Power Field (HPF) is the microscopy reference unit of the region under the maximum magnification power of the lens used, and the leukocytes in the microscopy unit of the autoanalyzer were measured in HPF (the area under the maximum ma- gnification power of the lens used, generally expressed as 400x magnification) unit.

Microscopic leukocyte values of the groups defined as negative, trace, $1+, 2+$ and $3+$, respectively, according to the leukocyte results in chemical analysis were recorded as HPF units. HPF values were plotted under chemical grouping. The arithmetic means of the leucocyte counts of each group were calculated respectively. The areas of the patients under the graphics were accepted as $100 \%$ in total. Charts were divided into percentiles. Percentiles were selected among the percentiles used in standard deviation and cut-off values were determined. Then, the ratio to fit the percentiles was multiplied by the total number of patients in that group, and the number of patients in that percentile was found. All HPF values were listed in each chemical group from minimum to maximum. The number of patients with the same HPF values was plotted against that HPF value. HPF values were matched so as to reach the total number of patients entering the percentile. Thus, the minimum and maximum HPF values of the patients were found. Percentages of $2.5 \%$ and $97.5 \%$ were used for minimum and maximum values.

Urine samples collected for culture were inoculated onto chromogenic medium with a $10 \mu 1$ loop, and evaluated after a $24-$ hour incubation at $37^{\circ} \mathrm{C}$.

\section{Statistical analysis}

NCSS (Number Cruncher Statistical System) 2007 Statistical Software (Utah, USA) program was used for statistical analysis. Mann-Whitney U test was used for intergroup comparisons of quantitative variables that did not show normal distribution, Spearman correlation analysis was used to evaluate the relationships between quantitative variables. Statistical significance was accepted as $\mathrm{p}<0.05$.

\section{Results}

Most frequently, obstetric outpatient clinic requested complete urinalysis (24\%), followed by outpatient clinics of internal diseases and pediatrics (Table 1). In chemical analysis, leukocyte measurements were grouped as negative, trace, $1+, 2+$ and $3+$, and their respective HPF values were recorded (Table 2). HPF values were plotted under chemical grouping (Figure 1a,b,c,d,e).

Figure 1. Distribution of leukocyte microscopy values in chemical analysis groups

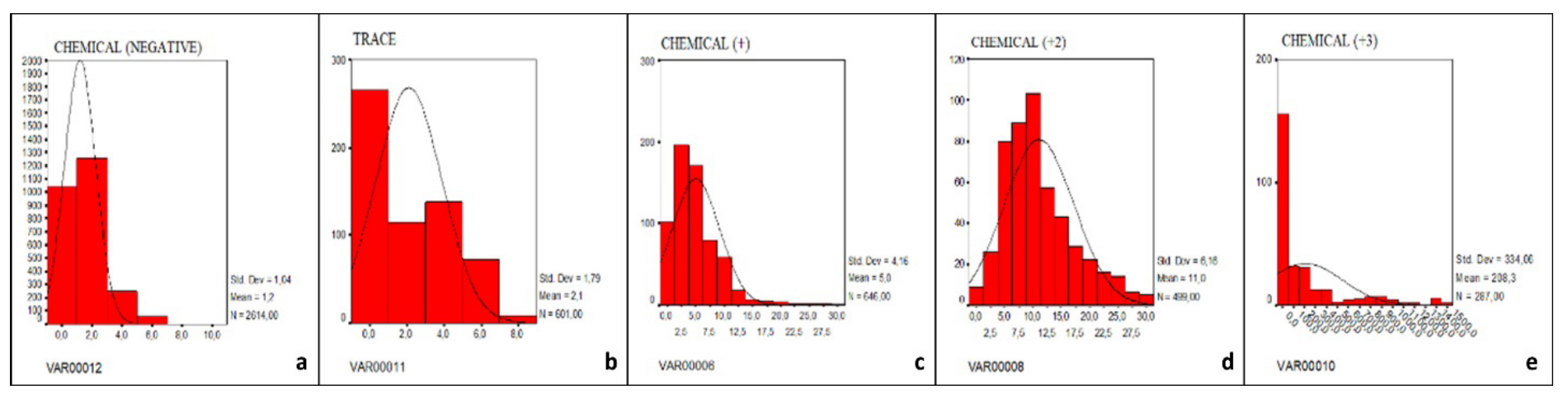

a) Negative, b) Trace, c) Positive (+), d) ++, e) +++ 
Table 1. Distribution of requests for complete urinalysis among polyclinics

\begin{tabular}{c|c}
\hline UNITS & \% \\
\hline Gynecology & 24 \\
\hline Internal Diseases & 22 \\
\hline Pediatry & 19.2 \\
\hline Urology & 13.6 \\
\hline General surgery & 6.6 \\
\hline *Others & 6.4 \\
\hline Infectious Diseases & 6.1 \\
\hline Emergency Medicine & 2.1 \\
\hline
\end{tabular}

*Dermatology, dentistry, physical therapy and rehabilitation, ophthalmology, otorhinolaryngology, neurology, orthopedics and psychiatry units are combined in the group named "others"

Leukocyte averages of each group were determined as 1.2, 2.1, 5.0, 11 and 208 white blood cells per high power field (WBCs/ HPF). HPF values corresponding to $2.5 \%$ and $97.5 \%$ percentiles were used for the minimum and maximum values, respectively. These HPF values were found as 0-4 WBCs/HPF for negative, 0-6 $\mathrm{WBCs} / \mathrm{HPF}$ for trace, 0-16 WBCs/HPF for $1+, 1-38 \mathrm{WBCs} / \mathrm{HPF}$ for 2+ and 1-1367 WBCs/HPF for 3+ according to the leukocyte counts under microscope (Table 3 ).

Leukocytes were evaluated together with the culture results (Table 4). Bacterial growth was detected in only 19 (16.8\%) out of 113 patients whose urine cultures were requested, and no reproduction was observed in the remaining 94 (83.2\%) patients. Correlations between the results of microscopy, chemical analysis and culture were found as $r=0.143$ and 0.211 , respectively $(\mathrm{p}>0.05, \mathrm{p}=0.006)$.

WBC counts of all analysis (culture, microscopy and chemical) were classified as positive and negative. Microscopy and chemical analysis values were compared with urine culture values. When the results of microscopic and chemical analyses were compared with the culture results; the analytical sensitivity, specificity, positive, and negative predictive values for urine microscopy were $25 \%, 86 \%, 61.3 \%$, and $58.3 \%$, respectively. Analytical sensitivity, specificity, positive, and negative predictive values of chemical analysis of urine were $25.8 \%, 87.7 \%$, $69.7 \%$, and 51.4\%, respectively (Table 5).

\section{Discussion}

Complete urinalysis (CUA) has been used as the oldest analytical test in clinical laboratories since the 19th century. Today, it is still accepted as one of the most valuable screening tests [5].

CUA is a combination of chemical and microscopic analysis. Chemical analyzes are evaluated using strips and cells are assessed visually under microscope. Chemical strips are standardized and day by day highly sensitive strips are produced. Microscopic analyzes have been carried out manually for years. Based on the experience of the laboratory staff, highly different results have been reported among laboratories or between different personnel in the same laboratory vaeying with the brand of the strip used [5-6].
Microscopic examination of the urine sediment, although not standardized, gives important clinical information concerning the characteristic features of leukocytes, epithelial cells and erythrocytes. Microscopic examination requires considerable time allocation by laboratory staff [5-6].

Since the second half of the 20th century, it has been aimed to minimize the errors stemming from the individual differences of materials, instruments and laboratory workers in order to provide accurate and reliable results in complete urinalysis. Thus, automated urine autoanalyzers have been used in clinical laboratories with higher patient potential. To deal with the disadvantages of manual microscopy, automated urine analyzers using several analytical techniques have been developed [7]. Currently, these devices are frequently used in medical laboratories to minimize the work force lost during manual microscopic examination.

In this study, we aimed to take a closer look at the microscopic WBC/HPF measurements of automated urine analyzers. Since it is more standard, HPF values were grouped according to the chemical strip results. In addition, the compatibility of leukocytes with urine culture was examined. Finally, it was planned to set a cut-off value or a reference range for $\mathrm{WBC} / \mathrm{HPF}$ so as to classify and standardize $\mathrm{WBC} / \mathrm{HPF}$ as is the case with chemical analysis values. In the study, we noticed that $0-4 \mathrm{WBCs} /$ HPF range found for the chemical leukocyte negative result was compatible with the $0-5 \mathrm{WBCs} / \mathrm{HPF}$ range provided by the manufacturer (Table 3). The ranges for other chemical leukocyte values were 0-6 WBCs/HPF for trace, 0-16 WBCs/HPF for 1+, 1-38 WBCs/HPF for 2+ and 1-1367 WBCs/HPF for $3+$.

Urinary tract infections are one of the most common infections and the first diagnostic test is complete urinalysis. Urine culture is still the 'gold standard' for detecting pathogens of urinary tract infections. However, many requested but unnecessary urine cultures cause loss of time and labor in laboratories. It is not uncommon for empirical antibiotic therapy to be applied while waiting for urine culture results of the patients. Rational treatment approaches should be applied to reduce costs and prevent development of antimicrobial resistance [8].

The HPF classification can help doctors identify real patients with urinary tract infections before requesting a culture. Since the CUA results are obtained within a short time after the sample is given, it can shorten the time to start treatment and reduce the number of requests for urine cultures. So, urinalysis is needed to support the diagnosis of UTI.

In our study, no correlation was found between results of culture and microscopic examination. Leukocyte values in chemical analysis correlated with urine culture results which may be due to the standardization of chemical analysis. Chemical analysis by automated urine analyzer, and microscopic examination correlate with urine culture results with analytical sensitivity rates of $25.8 \%$ and $25 \%$, respectively. These results show that positive chemical values do not support actual growth rates which suggests that it would be more appropriate for doctors to request a urine culture after clinical evaluation of the patient.

Microscopic and chemical analysis have respective analytical specificity rates of $86 \%$ and $87.7 \%$ in patients without growth in their urine cultures. These results support the fact that there will be no growth in urine cultures of patients with CUA devoid of WBCs. This finding may allow the doctor to monitor the patient without 
Table 2. HPF values in the grouping made according to the number of patients and leukocyte values

\begin{tabular}{|c|c|c|c|c|c|c|c|c|c|c|c|c|c|c|c|}
\hline \multirow{2}{*}{$\begin{array}{c}\text { neg } \\
\text { HPF }\end{array}$} & \multirow{2}{*}{$\begin{array}{c}\mathrm{n}=2668 \\
\text { Freq }\end{array}$} & \multirow{2}{*}{$\begin{array}{c}+ \\
\text { HPF }\end{array}$} & \multirow{2}{*}{$\begin{array}{c}\mathrm{n}=644 \\
\text { Freq }\end{array}$} & \multicolumn{2}{|c|}{$2+$} & \multicolumn{2}{|c|}{$\mathrm{n}=511$} & \multicolumn{4}{|c|}{$3+$} & \multicolumn{4}{|c|}{$\mathrm{n}=286$} \\
\hline & & & & HPF & Freq & HPF & Freq & HPF & Freq & HPF & Freq & HPF & Freq & HPF & Freq \\
\hline Rare & 1046 & 0.5 & 24 & 1 & 9 & 39 & 1 & Rare & 1 & 160 & 1 & 322 & 1 & 912 & 1 \\
\hline 1 & 1119 & 1 & 77 & 2 & 14 & 42 & 1 & 1 & 7 & 165 & 1 & 351 & 1 & 935 & 1 \\
\hline 2 & 307 & 2 & 105 & 3 & 12 & 43 & 1 & 10 & 20 & 167 & 1 & 352 & 1 & 969 & 1 \\
\hline 3 & 107 & 3 & 90 & 4 & 19 & 44 & 1 & 11 & 19 & 169 & 2 & 366 & 1 & 976 & 1 \\
\hline 4 & 42 & 4 & 53 & 5 & 17 & 45 & 2 & 12 & 23 & 170 & 1 & 370 & 1 & 1027 & 1 \\
\hline 5 & 31 & 5 & 46 & 6 & 42 & 50 & 1 & 13 & 23 & 174 & 1 & 380 & 1 & 1027 & 1 \\
\hline 6 & 6 & 6 & 73 & 7 & 48 & 54 & 1 & 14 & 29 & 178 & 1 & 386 & 1 & 1064 & 1 \\
\hline 7 & 1 & 7 & 47 & 8 & 40 & 55 & 1 & 15 & 30 & 184 & 1 & 388 & 1 & 1064 & 1 \\
\hline 8 & 1 & 8 & 31 & 9 & 32 & 68 & 1 & 100 & 1 & 188 & 1 & 394 & 1 & 1247 & 1 \\
\hline 9 & 3 & 9 & 29 & 10 & 34 & 74 & 1 & 101 & 2 & 197 & 1 & 416 & 1 & 1247 & 1 \\
\hline 11 & 1 & 10 & 15 & 11 & 36 & 88 & 1 & 102 & 2 & 198 & 1 & 441 & 2 & 1358 & 1 \\
\hline 13 & 1 & 11 & 14 & 12 & 34 & 97 & 1 & 103 & 1 & 199 & 1 & 442 & 1 & 1358 & 1 \\
\hline 14 & 1 & 12 & 9 & 13 & 23 & & & 104 & 1 & 202 & 1 & 444 & 1 & 1367 & 1 \\
\hline 28 & 1 & 13 & 8 & 14 & 14 & & & 106 & 1 & 210 & 1 & 464 & 1 & 1367 & 1 \\
\hline \multirow[t]{2}{*}{172} & 1 & 14 & 4 & 15 & 14 & & & 107 & 1 & 212 & 1 & 473 & 1 & 1375 & 1 \\
\hline & & 15 & 1 & 16 & 14 & & & 112 & 1 & 216 & 1 & 488 & 1 & 1375 & 1 \\
\hline Trace & $\mathrm{n}=576$ & 16 & 2 & 17 & 17 & & & 113 & 1 & 218 & 1 & 573 & 1 & 1483 & 1 \\
\hline HPF & Freq & 17 & 4 & 18 & 12 & & & 114 & 1 & 221 & 1 & 616 & 1 & 1483 & 1 \\
\hline Rare & 57 & 18 & 1 & 19 & 6 & & & 115 & 1 & 223 & 1 & 620 & 1 & 2488 & 1 \\
\hline 1 & 208 & 19 & 2 & 20 & 9 & & & 116 & 1 & 228 & 1 & 635 & 1 & 2685 & 1 \\
\hline 2 & 114 & 21 & 1 & 21 & 6 & & & 118 & 2 & 234 & 1 & 653 & 1 & 3340 & 1 \\
\hline 3 & 90 & 22 & 1 & 22 & 10 & & & 125 & 1 & 236 & 2 & 686 & 1 & & \\
\hline 4 & 46 & 23 & 1 & 23 & 5 & & & 127 & 1 & 240 & 1 & 689 & 1 & & \\
\hline 5 & 27 & 26 & 1 & 24 & 5 & & & 132 & 1 & 245 & 1 & 701 & 1 & & \\
\hline 6 & 15 & 27 & 1 & 25 & 1 & & & 134 & 1 & 249 & 2 & 721 & 1 & & \\
\hline 7 & 4 & 28 & 1 & 26 & 7 & & & 136 & 1 & 253 & 1 & 750 & 1 & & \\
\hline 8 & 5 & 30 & 1 & 27 & 2 & & & 138 & 2 & 254 & 1 & 766 & 1 & & \\
\hline 9 & 1 & 51 & 1 & 28 & 4 & & & 139 & 1 & 256 & 1 & 772 & 1 & & \\
\hline 11 & 2 & 86 & 1 & 29 & 3 & & & 140 & 1 & 264 & 1 & 787 & 1 & & \\
\hline 12 & 2 & & & 30 & 2 & & & 144 & 1 & 268 & 1 & 797 & 1 & & \\
\hline 14 & 2 & & & 31 & 1 & & & 145 & 2 & 277 & 1 & 810 & 1 & & \\
\hline 16 & 1 & & & 32 & 1 & & & 146 & 2 & 283 & 1 & 834 & 1 & & \\
\hline 18 & 1 & & & 34 & 2 & & & 149 & 2 & 284 & 1 & 863 & 1 & & \\
\hline \multirow[t]{3}{*}{36} & 1 & & & 35 & 1 & & & 151 & 1 & 295 & 1 & 869 & 2 & & \\
\hline & & & & 37 & 1 & & & 152 & 1 & 306 & 2 & 884 & 1 & & \\
\hline & & & & 38 & 1 & & & 157 & 1 & 315 & 1 & 908 & 1 & & \\
\hline
\end{tabular}

HPF: reported HPF values of patients; Freq: frequency; number of patients with the same HPF value; n: total number of patients belonging to the leukocyte group

using antibiotics and requesting a urine culture. Lesser use of antibiotics will also have a decreasing effect on the development of resistance to antibiotics. In studies with similar results, Lunn et al. determined the agreement between positive urine culture and chemically positive leukocyte results as $27 \%$, and suggested that this difference was due to the number of samples used [9].

In various publications, the presence of a good correlation has been demonstrated between automated device and microscope as for the detection of erythrocytes and leukocytes [10-12]. Any significant difference does not exist between the automated urine analyzer and the microscope. Nevertheless, it was determined that the automated analyzer overestimated cell counts in the presence of greater number of erythrocytes and leukocytes in the sample compared to the manual method. In the manual method, 
Table 3. Lower and upper reference values by percentiles in leukocyte grouping

\begin{tabular}{l|c|c|c|c|c|c}
\hline Negative leukocyte & $\mathrm{n}$ & $\%$ & $\%$ & $\%$ & $\%$ & $\%$ \\
\hline & 2668 & 2.5 & 68 & 95 & 97.5 & 99 \\
\hline & $(*)$ & 67 & 1814 & 2535 & 2601 & 2641 \\
\hline Trace leukocyte & $\mathrm{HPF}(* *)$ & $\mathbf{0}$ & $<1$ & 3 & $\mathbf{4}$ & 5 \\
\hline & $\mathrm{n}$ & $\%$ & $\%$ & $\%$ & $\%$ & $\%$ \\
\hline & 567 & 2.5 & 68 & 95 & 97.5 & 99 \\
\hline & $(*)$ & 14 & 386 & 539 & 553 & 561 \\
\hline & $\mathrm{HPF}(* *)$ & $\mathbf{0}$ & 2 & 5 & $\mathbf{6}$ & 7 \\
\hline & $\mathrm{n}$ & $\%$ & $\%$ & $\%$ & $\%$ & $\%$ \\
\hline & 644 & 2.5 & 68 & 95 & 97.5 & 99 \\
\hline & $(*)$ & 16 & 438 & 612 & 628 & 638 \\
\hline & $\mathrm{HPF}(* *)$ & $\mathbf{0}$ & 6 & 12 & $\mathbf{1 6}$ & 23 \\
\hline & $\mathrm{n}$ & $\%$ & $\%$ & $\%$ & $\%$ & $\%$ \\
\hline & 511 & 2.5 & 68 & 95 & 97.5 & 99 \\
\hline & $(*)$ & 13 & 347 & 485 & 498 & 506 \\
\hline & $\mathrm{HPF}(* *)$ & $\mathbf{1}$ & 13 & 28 & $\mathbf{3 8}$ & 54 \\
\hline & $\mathrm{n}$ & $\%$ & $\%$ & $\%$ & $\%$ & $\%$ \\
\hline & 286 & 2.5 & 68 & 95 & 97.5 & 99 \\
\hline & $(*)$ & 7 & 194 & 272 & 279 & 283 \\
\hline & $\mathrm{HPF}(* *)$ & $\mathbf{1}$ & 178 & 1064 & $\mathbf{1 3 6 7}$ & 1483 \\
\hline & 4676 & & & & & \\
\hline
\end{tabular}

(*): Number of patients entering the percentile; (**) Maximum HPF value of the relevant patients

Table 4. Distribution of the groups made in consideration of WBC counts according to the culture results

\begin{tabular}{l|c|c|c|c|c|c}
\hline & $\begin{array}{c}\text { Negative } \\
(\mathbf{n})\end{array}$ & $\begin{array}{c}\text { Trace } \\
(\mathbf{n})\end{array}$ & $\begin{array}{c}\mathbf{1 +} \\
(\mathbf{n})\end{array}$ & $\begin{array}{c}\mathbf{2 +} \\
\text { (n) }\end{array}$ & $\begin{array}{c}\text { T+ } \\
\text { (n) }\end{array}$ & $\begin{array}{c}\text { Total } \\
\text { (n) }\end{array}$ \\
\hline Gram- Negative Growth $\left(10^{5} \mathrm{CFU}\right)$ & 0 & 2 & 1 & 0 & 3 & $\mathbf{6}$ \\
\hline Gram- Positive Growth $\left(10^{5} \mathrm{CFU}\right)$ & 1 & 0 & 0 & 0 & 0 & $\mathbf{1}$ \\
\hline $10^{3}-10^{5}$ CFU Growth & 1 & 1 & 0 & 1 & 3 & $\mathbf{6}$ \\
\hline Contamination & 1 & 1 & 0 & 1 & 3 & $\mathbf{6}$ \\
\hline *Non-pathogenic Growth & 39 & 6 & 3 & 7 & 16 & $\mathbf{7 1}$ \\
\hline Sterile & 15 & 2 & 2 & 0 & 4 & $\mathbf{2 3}$ \\
\hline Total & $\mathbf{5 7}$ & $\mathbf{1 2}$ & $\mathbf{6}$ & $\mathbf{9}$ & $\mathbf{2 9}$ & $\mathbf{1 1 3}$ \\
\hline
\end{tabular}

* presence of non-infectious factors

Table 5. Comparison of urine culture and WBC counts with microscopic and chemical analysis

\begin{tabular}{|c|c|c|c|c|c|c|c|}
\hline \multirow{3}{*}{ 崩 } & 1 & 13 & 19 & \multirow{3}{*}{ 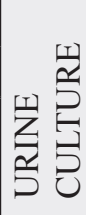 } & 1 & 10 & 23 \\
\hline & \multirow[t]{2}{*}{0} & 80 & 57 & & 0 & 70 & 66 \\
\hline & & 0 & 1 & & & 0 & 1 \\
\hline \multicolumn{3}{|l|}{$\mathrm{MICl}$} & & \multicolumn{3}{|c|}{ CHEMICAL } & \\
\hline
\end{tabular}

0: Negative; 1: Positive 
many steps such as centrifugation, pouring the supernatant and resuspension can cause lysis and loss of cells. Budak et al. found that leukocyte counts were overestimated with automated urine analyzers compared to the manual method [13]. The automated analyzer automatically resuspends the particles by injecting air into each sample before testing. This procedure can separate clusters of cells which may result in higher cell numbers than those recorded by manual counting methods under microscope. Therefore, underestimations due to leukocyte aggregates are less common in the manual method [13].

There were some limitations in the study, and because of inadequate number of positive cultures, generalizations about the urine cultures could not be made. In daily practice, since urine culture is requested after the result of CUA is seen, the patient gives two separate urine samples, and the urine becomes more concentrated or diluted depending on the amount of fluid taken, even on the same day, causing differences in results. The exclusion of urine density and nitrite values of the samples in this study did not allow the evaluation of the correlations among urine density, bacterial growth in culture and nitrite values. In cases where leukocytes are found in urinalysis without detection of bacterial growth in culture, presence of non-infectious factors, and microorganisms that do not proliferate in culture media should be kept in mind.

Complete urinalysis is not sufficient to diagnose UTI, and the urine culture is essential. Nevertheless, in the future, the use of chemical reactions of microorganisms on strips and different magnification techniques such as HPF in microscopic units may make it easier to diagnose UTI.

\section{Conclusion}

The workload of medical laboratories is gradually increasing, and the use of urine autoanalyzers may be preferred for busy laboratories. The compatibility of the microscopy and chemical units of these devices can be closely monitored through quality control studies. Complete UA using autoanalysers in the diagnosis and follow-up of urinary tract infections may reduce unnecessary requests, and requirements for urine culture. This approach can reduce the cost burden and ease the workload of the laboratories. In addition, it can shorten the waiting time of patients and doctors for the results of the examinations by ensuring standardization of CUA results. This process can become more practical, especially in places such as emergency outpatient clinics, where a quick decision is required and faster patient circulation is desired.

Ethics Committee Approval: The study was approved by University of Health Sciences, Dr. Sadi Konuk Training and Research Hospital Ethical Committee, Bakirkoy, Istanbul, Turkey (Decision No: 2019/506).

Informed Consent: An informed consent was obtained from all the patients.

Publication: The results of the study were not published in full or in part in form of abstracts.

Peer-review: Externally peer-reviewed.

Authorship Contributions: Any contribution was not made by any individual not listed as an author. Concept - M.K., N.I.,
R.K.,E.G., Design - M.K., N.I., R.K., Supervision - M.K., N.I.,E.G., Resources - R.K., G.S.E., P.A., F.A., Materials R.K., G.S.E., P.A., F.A., Data Collection and/or Processing R.K., G.S.E., P.A., F.A., Analysis and/or Interpretation - M.K., N.I., R.K., G.S.E., P.A., F.A., Literature Search - R.K., G.S.E., P.A., F.A., Writing- M.K., N.I., R.K., G.S.E., Critical Review M.K., N.I., E.G.

Conflict of Interest: The authors declare that they have no conflict of interest.

Financial Disclosure: The authors declare that this study received no financial support.

\section{References}

[1] Patel HD, Livsey SA, Swann RA, Bukhari SS. Can urine dipstick testing for urinary tract infection at point of care reduce laboratory workload? J Clin Pathol. 2005;58:951-4. https://doi.org/10.1136/jcp.2004.025429.

[2] Valenstein P, Meier F. Urine culture contamination: a College of American Pathologists Q-Probes study of contaminated urine cultures in 906 institutions. Urinalysis and urinary tract infection: update for clinicians. Arch Pathol Lab Med 1998;122:123-31.

https://pubmed.ncbi.nlm.nih.gov/9499354/.

[3] Young JL, Soper DE. Urinalysis and urinary tract infection: update for clinicians. Infect Dis Obstet Gynecol 2001;9:249-55.

https://doi.org/10.1155/S1064744901000412.

[4] Whiting P, Westwood M, Watt I, Cooper J, Kleijnen J. Rapid tests and urine sampling techniques for the diagnosis of urinary tract infection (UTI) in children under five years: a systematic review. BMC Pediatr 2005;5:4. https://doi.org/10.1186/1471-2431-5-4.

[5] Fogazzi GB, Cameron JS, Ritz E, Ponticelli C. The history of urinary microscopy to the end of the 19th century. Am J Nephrol 1994;14:452-7.

https://doi.org/10.1159/000168764.

[6] Yaoo YM, Tatsumi N, Kirihigashi K, Narita M, Tsuda I, Kawamoto $\mathrm{T}$, et al. Inaccuracy and inefficiency of urinary sediment analysis. Osaka City Med J 1995;41:41-8. https://pubmed.ncbi.nlm.nih.gov/8778645/.

[7] Yalcinkaya E, Erman H, Kirac E, Serifoglu A, Aksoy A, Isman FK, et al. Comparative Performance Analysis of Urised 3 and DIRUI FUS-200 Automated Urine Sediment Analyzers and Manual Microscopic Method. Medeni Med J. 2019;34:244-51. https://doi.org/ 10.5222/MMJ.2019.23169.

[8] Polat C, Evliyaoglu O, Erkan REC, Basturk A, Cakir T, Aslaner A, et al. A comparison of urine microscopy and urine culture results of patients considered to have urinary tract infection. Am J Exp Clin Res 2015;2:118-20. http://ajecr.org/index.php/ajecr/article/view/46.

[9] Lunn A, Holden S, Boswell T, Watson AR. Automated microscopy, dipsticks and the diagnosis of urinary tract infection. Arch Dis Child 2010;95:193-7. https://doi.org/ 10.1136/adc.2009.166835. 
[10] Chien TI, Kao JT, Liu HL, Lin PC, Hong JS, Hsieh HP, et al. Urine sediment examination: a comparison of automated urinalysis systems and manual microscopy. Clin Chim Acta 2007;384:28-34.

https://doi.org/10.1016/j.cca.2007.05.012.

[11] Linko S, Kouri TT, Toivonen E, Ranta PH, Chapoulaud E, Lalla M. Analytical performance of the Iris iQ200 automated urine microscopy analyzer. Clin Chim Acta 2006;372:54-64.

https://doi.org/10.1016/j.cca.2006.03.015.
[12] Wah DT, Wises PK, Butch AW. Analytic performance of the iQ200 automated urine microscopy analyzer and comparison with manual counts using Fuchs-Rosenthal cell chambers. Am J Clin Pathol 2005;123:290-6. https://pubmed.ncbi.nlm.nih.gov/15842056/.

[13] Budak YU, Huysal K. Comparison of three automated systems for urine chemistry and sediment analysis in routine laboratory practice. Clin Lab 2011;57:47-52.

https://pubmed.ncbi.nlm.nih.gov/21391464/. 